\title{
EKSPLORASI PERDAGANGAN DAGING ANJING SEBAGAI PENDUKUNG PERANCANGAN FILM ANIMASI PENDEK
}

\author{
Mathilda Eleonora ${ }^{1)}$, Frans Santoso ${ }^{2)}$ \\ School of Design, Universitas Bina Nusantara \\ Jl. K. H. Syahdan No. 9, Kemanggisan, Palmerah, Jakarta 11480, Indonesia \\ Ithilda04@gmail.com, ${ }^{2}$ frans@binus.ac.id
}

\begin{abstract}
Abstrak
Penelitian ini dilakukan untuk mengeksplorasi perdagangan daging anjing yang sedang terjadi di Indonesia, dengan tujuan perancangan konsep dalam pembuatan animasi pendek yang akan dilakukan di masa depan. Walau tidak banyak masyarakat Indonesia yang mengonsumsi daging anjing, perdagangan daging anjing di Indonesia menjadi salah satu permasalahan yang disorot oleh para organisasi perlindungan hewan baik secara nasional maupun internasional. Hasil penelitian yang didapatkan menunjukkan bahwa dalam proses perdagangan daging anjing terjadi kekejaman yang tidak manusiawi serta mengonsumsi daging anjing yang tidak diregulasi menyebabkan dampak negatif terhadap kesehatan manusia. Dengan kategori Original Story, penulis menggunakan tema perdagangan daging anjing dan disampaikan kepada masyarakat melalui animasi pendek, dengan tujuan membantu mengurangi dan menyadarkan masyarakat untuk menghentikan perdagangan dan mengonsumsi daging anjing.
\end{abstract}

Kata Kunci: Animasi Pendek, Perdagangan Daging Anjing, Original Story

\begin{abstract}
This research was conducted to explore dog meat trade that is a daily occurrence in Indonesia, the aim of this research is for the concept design in making a short animation that will be done in the future. Although only small communities in Indonesians consume dog meat, the dog meat trade in Indonesia is one of the problems highlighted by animal protection organizations both nationally and internationally. The obtained results of this research showed that in the process of the dog meat trade there was inhumane cruelty and consuming unregulated dog meat had a negative impact on human health. Categorized in Original Story, the author uses the theme of dog meat trade and delivered the results to the public through short animations, the aim of this short animation is to help reduce and if possible, stopped the dog meat trade and consumption in Indonesia.
\end{abstract}

Keywords: Short Animation, Dog Meat Trade, Original Story

\section{PENDAHULUAN}

Indonesia adalah salah satu Negara terbesar di dunia, dengan memiliki penduduk sebanyak 265 juta jiwa dan menempati posisi ke-4 dengan penduduk terbanyak di dunia. Indonesia adalah Negara yang sedang berkembang, sehingga masih banyak terlihat keterbelakangan di antara para penduduk. Salah satu hal yang cukup memprihatinkan di Indonesia adalah kurangnya rasa kepedulian para masyarakat terhadap binatang. Terdapat banyak kasus menyedihkan berkaitan dengan penganiayaan binatang-binatang di Indonesia terutama konsumsi daging hewan tersebut secara illegal, salah satu adalah hewan anjing. Banyak rakyat di Indonesia yang memelihara anjing, tetapi banyak juga anjing liar yang berkeliaran di jalanan. 
Di negara-negara asia sendiri memiliki banyak negara yang masih mengonsumsi daging anjing hingga sekarang, berdasarkan kampanye Dog Meat Free Indonesia (DMFI, 2018b) dikatakan bahwa banyak negara Asia yang masih percaya bahwa mengonsumsi daging anjing dapat memberikan khasiat positif bagi tubuh, misalnya daging anjing dapat menyembuhkan asma, demam berdarah, penyakit tubuh, dan sebagai vitamin. Tentu negara Indonesia menjadi salah satu negara yang masih mengonsumsi daging anjing, walaupun dengan jumlah yang sedikit. Pada dasarnya, dari perdagangan daging anjing itu sendiri dapat menyebabkan banyak dampak negatif bagi masyarakat.

Salah satu kasus terkenal tentang perdagangan daging anjing, yaitu terjadi pada pertengahan tahun 2017, banyaknya turis yang mendatangi Pulau Bali tertipu dengan memakan sate berkedok daging ayam yang ternyata adalah sate daging anjing. Kasus tersebut mendapatkan banyak perhatian dari negara lain, banyak berita negara lain dan artikel-artikel yang menyorot kasus kekejaman proses perdagangan daging anjing serta memberikan peringatan kepada para turis yang akan datang ke negara Indonesia. Dr.Syamsul Ma'arif DVM, M.Si. (Director of Veterinary Public Health) mengatakan bahwa "banyak negara lain menganggap rendahnya kesejahteraan dan kekejaman pada hewan tidak layak atau tidak pantas, sehingga banyak turis akan berhenti datang berwisata ke negara Indonesia dan dapat memberikan dampak buruk kepada turisme Indonesia".

Penghentian dan pencegahan perdagangan daging di Indonesia sulit untuk diatasi karena banyak daerah-daerah di Indonesia yang memiliki budaya mengonsumsi daging anjing, seperti kota Solo. Dikatakan dalam berita Kompas.com bahwa dalam sehari kota Solo dapat mengonsumsi 1.200 ekor anjing. Dituliskan dalam berita tersebut, FX Rudyatmo yakni selaku Wali Kota Solo mengatakan bahwa mereka tidak bisa melarang rakyatnya untuk mengonsumsi daging anjing, dikarenakan tidak adanya regulasi yang dapat dilakukan untuk melarang rakyatnya. Dikatakan juga bahwa tradisi kuliner mengonsumsi daging anjing sudah ada sejak dahulu (Hardoko, 2018).

Banyaknya kasus perdagangan daging anjing telah menarik perhatian para pencinta dan perlingungan kesejahteraan hewan dari negara lain. Oleh sebab itu, banyaknya komunitas dan organisasi terbentuk dan bekerja sama untuk menangani perdagangan daging anjing tersebut. Di Indonesia sendiri masih banyak masyarakat tidak menyadari permasalahan tersebut.

\section{Tinjauan Pustaka \\ Hewan Anjing}

Berdasarkan buku "The Intelligence of Dogs" (Coren, 1994), sejak 140 abad yang lalu, manusia dan anjing telah hidup berdampingan. Anjing membantu manusia memburu dan menggiring peternakan, anjing juga berperan sebagai panduan, pelindungan rumah, kolektor sampah, membantu transportasi, sebagai kawan saat perang, dan juga berbagai peran anjing lainnya dalam kehidupan manusia. Anjing adalah hewan mamalia yang telah didomestikasi dari hewan serigala sejak seratus ribuan tahun yang lalu, tetapi dari hasil penelitian DNA terbaru mengatakan bahwa anjing muncul pada akhir era Pleistosen (era yang berlangsung 2.588.000-11.500 tahun yang lalu).

Dari buku tersebut juga mengatakan bahwa, hewan bernama miacis adalah leluhur hewan anjing. Miacis adalah hewan yang tinggal sekitar 40 juta tahun yang lalu. Miacis adalah hewan dengan besar badan serupa dengan hewan cerpelai, miacis juga memiliki kaki yang pendek, ekor, badan, serta leher yang panjang, miacis juga memiliki telinga yang lancip. Dikatakan bahwa hewan miacis adalah leluhur dari famili Canidae (hewan yang termasuk dalam famili ini adalah anjing, serigala, rubah, koyote, jakal, dan dingo), buku tersebut juga mengatakan bahwa hewan miacis adalah leluhur semua hewan beruang dan juga semua hewan kucing. Anjing sendiri memiliki berbagai macam ras, Federation Cynologique Internationale (FCI) atau dengan nama lain World Canine Organization mendata terdapat 340 ras anjing. 


\section{Hubungan manusia dengan hewan}

Sejak masa purba, manusia dan hewan hidup berdampingan, tetapi dari hubungan antara manusia dengan hewan tersebut terdapat sisi positif dan negatif. Dari sisi negatif, manusia telah mengambil banyak keuntungan dari hewan, contohnya menggunakan hewan untuk memenuhi kebutuhan primer manusia (pakaian, makanan, dan sebagainya), hewan juga sering kali digunakan sebagai makhluk eksperimen dalam riset laboratorium, dan juga kegunaan lainnya yang dimanfaatkan oleh para manusia.

Pada tanggal 24 September 2018, organisasi Peta (People for the Ecthical Treatment of Animals) menyatakan kemenangan atas keberhasilan mereka untuk mengajak masyarakat untuk melarang menggunakan bulu luak (badger) sebagai bulu untuk kuas atau alat kecantikan. Kejadian tersebut berlangsung di Cina, dimana sebuah perusahaan membunuh luak untuk mengambil bulu mereka. Kasus tersebut merupakan salah satu kasus manusia menggunakan hewan demi memenuhi kemewahan. Masih banyak perusahaan besar yang membunuh hewan demi keuntungan yang besar, salah satunya adalah perusahaan Farfetch, yakni retail busana besar yang berpusat di London, United Kingdom. Organisasi Peta telah mencoba untuk mengajukan larangan penggunaan bulu hewan sebagai bahan busana, tetapi perusahaan tersebut masih belum juga menerima larangan tersebut sebagai salah satu kebijakan perusahaan mereka. Organisasi Peta masih berjuang untuk melarang dan memberantas perusahaan atau organisasi kecil yang menyiksa dan menyalahgunakan hewan.

Dibalik itu semua ada juga sisi positif hubungan manusia dengan hewan, tidak semua manusia menggunakan hewan demi kepuasan materialistik. Dari artikel "Phsycholosocial dan Pschopsysiological effects of human-animal interactions: the possible role of oxytocin" (Beetz dkk., 2012), mengatakan bahwa interaksi antara manusia dengan hewan memberikan banyak keuntungan, terutama bagi kesehatan dan kondisi mental manusia, dari hasil riset yang tertera dalam artikel tersebut disebutkan interaksi antara manusia dengan hewan menyebabkan:

1. Meningkatnya hubungan intrapersonal, hubungan sosial, sifat, dan mood.

2. Berkurangnya parameter hal negatif yang berhubungan dengan stres, seperti kortisol, detak jantung, dan tekanan darah.

3. Berkurangnya rasa takut dan panik.

4. Meningkatnya kesehatan mental dan fisik terutama kesehatan kardiocaskular.

Peningkatan plasma OT (oxytocin), prolactin, phenylacetic acid, dan dopamine terjadi pada manusia dan anjing, setelah 5 hingga 24 menit manusia mengelus hewan anjing. Interaksi positif dan afeksi antara manusia dengan hewan memengaruhi peningkatan OT (oxytocin) (Odendaal \& Meintjes, 2003).

\section{Kondisi Hewan Anjing di Jakarta}

Jakarta adalah ibukota negara Indonesia, di Jakarta sendiri memiliki \pm 10.4 juta jiwa. Banyak penduduk di kota Jakarta memiliki hewan peliharaan terutama hewan anjing dan kucing. Berdasarkan jurnal yang didapatkan mengenai "Perancangan Kampanye Sosial Sterilisasi untuk Hewan Peliharaan di Jakarta" (Sulistiyarini dan Fadhila, 2017), dikatakan bahwa populasi hewan domestik atau hewan peliharaan di Indonesia sudah sangat tinggi dan harus dilakukan tindakan untuk mengatasi permasalahan tersebut. Seekor kucing betina dapat melahirkan \pm 12 anak kucing, sedangkan seekor anjing betina dapat melahirkan $\pm 13-18$ anak anjing, maka dari itu populasi tinggi (over-populasi) hewan peliharaan dapat menimbulkan banyak permasalahan, salah satunya adalah dengan over-populasi hewan peliharaan dapat menimbulkan penelantaran hewan atau pembuangan hewan. Dari penelantaran atau pembuangan tersebut menyebabkan banyaknya hewan yang berkeliaran secara liar. Hal tersebut menyebabkan banyaknya hewan yang kelaparan, tertabrak oleh kendaraan, dianiaya oleh masyarakat, ditangkap dan diperjual-belikan dagingnya, digunakan untuk ber-adu dengan anjing lain, dan sebagainya. Terdapat organisasi seperti Jakarta Animal Aid Network (JAAN) bekerja keras dalam menangani permasalahan sejenis. 


\section{Perdagangan dan konsumsi daging anjing di Indonesia}

Di Indonesia sendiri, masyarakat yang mengonsumsi daging anjing memiliki jumlah yang sangat sedikit. Salah satu daerah yang menjadikan konsumsi daging anjing menjadi tradisi kuliner adalah Sulawesi Utara (Manado). RW, singkatan dari Rintek Wuuk (dalam bahasa Manado artinya bulu halus) merupakan makanan berbahan dasar anjing yang merupakan hidangan wajib setiap kali perhelatan (pernikahan) pesta di Sulawesi Utara (Windratie,2015).

Banyak anjing-anjing liar yang berkeliaran mengidap penyakit rabies karena kondisi kesehatan hewan di Indonesia masih belum diregulasi. Dalam laporan "Jangan ada Lagi Kematian Akibat Rabies", dari info Pusat Data dan Informasi Kementrian Kesehatan RI 2016. Dikatakan bahwa di Indonesia hewan penular utama, yaitu anjing (98\%), serta monyet dan kucing (2\%). Dilaporkan juga distribusi kasus kematian akibat rabies (tahun 2013-2015) berdasarkan provinsi, dari grafik tersebut dilaporkan bahwa Sulawesi Utara memiliki jumlah kematian akibat rabies paling tinggi (PUSDATIN, 2016).

Sulawesi Utara terdapat Pasar Ekstim Tomohon, yang isinya terdapat penjual-penjual yang menawarkan berbagai macam daging hewan eksotis, dan salah satunya tentu daging anjing. Bukti terbaru mengenai risiko rabies muncul dalam bentuk karkas anjing positif rabies yang ditemukan dijual untuk konsumsi manusia di pasar Sulawesi Utara (DMFI, 2018a).

\section{Undang-Undang Perlindungan Terhadap Hewan}

Indonesia memiliki undang-undang dalam perlindungan hewan dan peternakan, undang-undang tersebut yakni undang-undang republik Indonesia nomor 18 tahun 2009 tentang Peternakan dan Kesehatan Hewan. Dalam undang-undang tersebut terdapat pasal yang berisikan tentang kesejahteraan hewan atau perlindungan penganiayaan hewan:

1. Pasal 66: Kesejahteraan Hewan

2. Pasal 91: Ketentuan Pidana

Pada tahun 2014 dikeluarkan undang-undang nomor 41 tentang perubahan undangundang nomor 18 tahun 2009 tentang Peternakan dan Kesehatan Hewan. Dalam undang-undang Republik Indonesia nomor 41 tahun 2014 terdapat beberapa perubahan Pasal yang berkaitan dengan penganiayaan hewan, yakni:

1. Di antara Pasal 66 dan Pasal 67 disisipkan 1 (satu) Pasal yakni Pasal 66A sehingga berbunyi sebagai berikut:

a. Pasal 66A

1) Setiap Orang dilarang menganiaya dan/atau menyalahgunakan Hewan yang mengakibatkan cacat dan/atau tidak produktif.

2) Setiap Orang yang mengetahui adanya perbuatan sebagaimana dimaksud pada ayat (1) wajib melaporkan pada pihak yang berwenang.

2. Di antara Pasal 91 dan Pasal 92 disisipkan 2 (dua) pasal yakni Pasal 91A dan Pasal 91B sehingga berbunyi sebagai berikut:

a. Pasal $91 \mathrm{~A}$

1) Setiap Orang yang memproduksi dan/atau mengedarkan Produk Hewan dengan memalsukan Produk Hewan dan/atau menggunakan bahan tambahan yang dilarang sebagaimana dimaksud dalam Pasal 58 ayat (6), dipidana dengan pidana penjara paling lama 5 (lima) tahun dan pidana denda paling banyak Rp10.000.000.000,00 (sepuluh miliar rupiah).

b. Pasal 91B

1) Setiap Orang yang menganiaya dan/atau menyalahgunakan Hewan sehingga mengakibatkan cacat dan/atau tidak produktif sebagaimana dimaksud dalam Pasal 66A ayat (1) dipidana dengan pidana kurungan paling singkat 1 (satu) bulan dan paling lama 6 (enam) bulan dan denda paling sedikit Rp1.000.000,00 (satu juta rupiah) dan paling banyak Rp5.000.000,00 (lima juta rupiah).

2) Setiap Orang yang mengetahui adanya perbuatan sebagaimana dimaksud dalam Pasal 66A ayat (1) dan tidak melaporkan kepada pihak yang berwenang sebagaimana 
dimaksud dalam Pasal 66A ayat (2) dipidana dengan pidana kurungan paling singkat 1 (satu) bulan dan paling lama 3 (tiga) bulan dan denda paling sedikit Rp 1.000.000,00 (satu juta rupiah) dan paling banyak Rp 3.000.000,00 (tiga juta rupiah).

Sebagai pelengkap, dalam undang-undang hukum pidana terdapat ketentuan perlindungan untuk hewan, dapat dilihat pada KUHP (Kitab Undang-Undang Hukum Pidana), yakni:

(BUKU 2: KEJAHATAN) BAB XIV: Kejahatan Terhadap Kesusilaan

1. Pasal 302

2. Pasal 406

3. Pasal 540 seperti:

Terdapat juga undang-undang lainnya yang menopang kasus penganiayaan hewan,

1. Praktik kekerasan: termasuk pemikulan, penusukan, pencekikan, dan pembuangan hewan

a. KUHP pasal $302,406,335,170,540$

b. Hukuman: maksimal 12 tahun penjara

2. Pengandangan dan perantaian (kandang yang tidak layak, kekurangan air atau makanan/penyiksaan)

a. KUHP pasal 302, 406, 540, 335

b. Hukuman: maksimal 2 tahun penjara

3. Pertarungan anjing terorganisir

a. KUHP pasal 241, 302, 406, 170

b. Hukuman: maksimal 12 tahun penjara

Pada tanggal 25 September 2018, Pemerintah mengeluarkan peraturan yang dimuat dalam surat edaran Ditjem peternakan dan kesehatan hewan (PKH) kementan no.9874/SE/pk.420/F/09/2018. Surat itu sendiri juga bertuliskan tentang peningkatan pengawasan terhadap "Peredaran Perdagangan Daging Anjing".

\section{METODE PENELITIAN}

\section{Metode Kualitatif}

Pendekatan yang digunakan dalam riset ini adalah pendekatan kualitatif. Pendekatan kualitatif mementingkan kualitas data yang didapatkan, yang berarti data yang didapatkan tidak hanya sekadar jumlah atau statistik, melainkan mengutamakan kedetailan dan kedalaman dari data yang didapatkan.

\section{Teknik Pengumpulan Data}

Teknik Dokumentasi / Kepustakaan

Data akan didapatkan dari kepustakaan atau buku-buku dan artikel yang bersangkutan dengan tema.

Teknik Wawancara

Data juga akan didapatkan dari hasil wawancara yang mendalam dari narasumber yang bersangkutan dengan tema.

Teknik Obeservasi

Penulis akan melakukan observasi proses dari tema yang bersangkutan, sehingga penulis dapat menuliskan hasil data dengan detail dari hasil observasi yang dilakukan. 


\section{Metode Perancangan}

Define

Proses define bertujuan untuk memahami dan menjalani projek agar sesuai pada jalannya dan tidak keluar dari topik yang sudah ditentukan. Penulis harus mendefinisikan permasalahan yang dihadapi dalam perancangan ini. Proses ini juga membantu untuk mengetahui solusi yang tepat untuk menyelesaikan permasalahan yang ada. Dalam proses ini, akan menggunakan $5 \mathrm{~W}+1 \mathrm{H}$ :

What : Solusi apa yang pantas untuk diimplementasikan?

Solusi desain projek ini akan diimplementasikan dalam bentuk animasi pendek atau short animation. Animasi pendek ini akan menggunakan genre fantasi.

When : Berapa lama projek berlangsung?

Projek ini berlangsung selama 2 semester. Mulai dijalankan pada semester 7, pre-produksi dijalankan seperti riset, pengumpulan data, pembuatan konsep, pembuatan karakter, dan sebagainya. Kemudian production dan post-production dilakukan pada semester selanjutnya, yaitu semester 8 .

Where : Di mana projek ini akan ditampilkan?

Projek ini pantas ditampilkan pada sosial media seperti facebook, instagram, atau youtube, dengan tujuan animasi pendek dapat ditonton oleh banyak orang dan pesan dapat tersampaikan tidak hanya kepada target audience yang telah ditentukan.

Who : Siapakah target audience?

Target audience proyek ini adalah umur 12-17 tahun. Jangka umur 12-17 tahun adalah saat anakanak membentuk kepribadian dan dapat mengambil keputusan dengan sendirinya. Penulis memilih target audience umur 12-17 tahun karena penulis ingin menyampaikan pesan agar dapat membangun kesadaran diri.

Why : Mengapa solusi tersebut dibutuhkan?

Animasi pendek dapat menyampaikan pesan baik dalam segi moral cerita maupun emosi karakter kepada para audience lebih mendalam. Penulis ingin menggambarkan situasi kehidupan seekor anjing pada saat sebelum ditangkap dan diperdagangkan dagingnya. Dengan tema fantasi, panulis akan mensubtitusi karakter anjing sebagai boneka anjing, dengan tujuan penulis ingin menyampaikan kekejian yang terjadi, tetapi masih dapat ditayangkan kepada target audience yang sudah ditentukan.

How : Bagaimana cara mengimplementasikan perancangan ini?

Implementasi perancangan ini dapat dibaca lebih lanjut dalam laporan.

\section{Research}

Setelah melakukan proses define, penulis melanjutkan proses research atau riset. Penulis akan mengumpulkan data yang bersangkutan dengan topik projek yang sedang dilakukan. Akan meriset dan mengumpulkan 2 jenis data, yaitu data primer dan data sekunder:

Data primer: Data ini didapatkan dai hasil projek sejenis yang sebelumnya sudah pernah dilakukan. Dari data tersebut dapat dilihat langkah yang dapat diambil serta apa yang berhasil dan juga apa yang tidak berhasil.

Data sekunder: Data ini didapatkan dari laporan penelitian pasar konsumen. Tersebut memberikan gambaran demografik dan juga sejarah kinerja pasar serta segmentasi pasar. Data tersebut juga memberikan gambaran jelas struktur pasar.

\section{Ideate}

Pada proses ini, data yang didapatkan lalu diproses dan menggabungkannya pada permasalahan yang sudah disebutkan pada fase define. Dengan informasi yang sudah ada, akan digunakan untuk membuat perancangan desain. Hasil dari proses ini dapat dilihat pada bab 4.

\section{Prototype}

Prototype memberikan gambaran visualisasi pada hasil akhir yang akan dilakukan. Tujuan prototype adalah untuk meguji aspek tertentu dari solusi desain dan dapat dievaluasi. 


\section{HASIL DAN PEMBAHASAN}

\section{Wawancara dengan Animal Defenders Indonesia}

Sebagai data pada riset ini, penulis mencari narasumber yang memiliki ilmu dalam dunia penyelamatan hewan (animal rescue) serta penampungan anjing. Penulis melakukan wawancara kepada Doni Herdaru Tona, yakni ketua dari Animal Defenders Indonesia. Animal Defenders Indonesia adalah organisasi yang bergerak dalam bidang penyelamatan hewan terutama kucing dan anjing liar, serta menampung dan merawat hewan-hewan tersebut hingga kembali dalam kondisi bugar dan dapat diadopsi oleh masyarakat yang berminat. Dari hasil wawancara yang telah dilakukan dengan Doni Herdaru Tona, dapat disimpulkan:

1. Geolokasi dari rating laporan penelantaran: 1. Jakarta Barat; 2. Jakarta Utara; 3. Tangerang; 4. Bekasi; 5. Jakarta Timur; 6. Jakarta Selatan; 7. Jakarta Selatan.

2. kondisi hewan-hewan yang ditemukan $80 \%$ urgensi fisik (seperti luka terbuka, patah tulang, dan sebagainya), dan $20 \%$ urgensi psikis/psikologi.

3. Kasus yang paling parah adalah kasus anjing-anjing yang ditangkap untuk dimakan, tetapi lolos. Dan kasus seperti ini banyak terjadi.

4. Inti dari permasalahan di Indonesia adalah penegakan hokum yang masih tebang pilih. Undang-undang perlindungan hewan ada, tetapi tidak pernah ditegakkan karena dianggap bukan kepentingan yang wajib untuk dilaksanakan sekarang.

5. Anjing lokal (Mongrel) adalah favorit pemakan daging anjing. Dan anjing besar juga salah satu target bagi para favorit pemakan daging anjing.

6. Proses supply daging anjing sangat brutal: menangkap, menyeret, memukul, meracun, dan lain-lainnya. Terdapat anjing yang berhasil lolos dari proses tersebut, tetapi dalam kondisi yang hancur atau cacat.

7. Perbandingan anjing yang ditangkap dan dianiaya untuk dimakan memiliki jumlah lebih besar dibandingkan dengan anjing yang dianiaya demi kesusilaan pribadi.

8. Terdapat sindikat dalam dunia perdagangan daging anjing.

\section{Wawancara dengan Fieranny Halita}

Fierrany Halita adalah alumni dari Binus University jurusan Desain Komunikasi Visual Animasi. Animasi pendek "Acquiescence" adalah animasi pendek karya Fierrany Halita, dan telah memenangkan banyak penghargaan. Kini Fierrany Halita bekerja di BASE Animasi. Dari hasil wawancara yang telah dilakukan dengan Fierrany Halita, dapat disimpulkan:

1. Secara pribadi, Fierrany Halita lebih memilih animasi 2D karena peluang eksplorasi style yang lebih bebas dibandingkan dengan animasi 3D.

2. Secara keseluruhan, kesulitan dalam pembuatan animasi 2D adalah waktu. Produksi animasi 2D memakan banyak waktu dibandingkan dengan animasi 3D.

3. Mengaplikasikan depth dalam animasi 2D cukup sulit.

4. Fondasi yang paling penting dalam menarik perhatian para audience adalah story dan disesuaikan dengan target audience.

5. Untuk menyampaikan pesan atau emosi yang ingin disampaikan kepada audience melalui animasi yang ditayangkan, yang paling penting adalah timing.

6. Untuk membuat suatu karakter yang menarik untuk mendukung cerita, harus disesuaikan dengan target audience. Karakter loveable sesuai dengan target audience yang sudah di tentukan.

\section{Ringkasan Cerita}

Premis: Dua ekor anjing yang menjalani kehidupan sehari-hari, tetapi suatu hari mereka ditangkap.

Sepasang sahabat bernama Kuu dan Ket selalu bermain bersama sambil mencari bahan makanan untuk bertahan hidup. Dimulai dari memetik buah dari pohon yang tinggi dan juga memancing. Pada akhir hari, dengan riang mereka membawa hasil tangkapan mereka menuju tenda mereka. Dalam tengah perjalanan, mereka melewati gua yang terlihat misterius. Dengan rasa penasaran, mereka menghampiri gua tersebut. Isi gua tersebut terbuat dari Kristal-kristal gula 
(Rock Candy) warna-warni. Kuu dan Ket yang sedang berdiri di mulut gua, hendak memasuki gua tersebut, tetapi tiba-tiba seseorang memukul kepala mereka dari belakang.

Hilang kesadaran, Kuu dan Ket diseret dan diletakkan bersampingan. Sebuah api membara dari bawah Kuu dan Ket, api tersebut membakar Kuu dan Ket yang sedang hilang kesadaran. Faktanya, Kuu dan Ket sudah di produksi dan daging mereka sedang dibakar diatas panggangan, dijadikan satu untuk disajikan kepada konsumen pada suatu warung yang menyediakan masakan daging anjing.

\section{Perancangan Judul}

Perancangan judul menggunakan kata cooked dan disedernakan menjadi "kuuket". Judul "Kuu Ket" juga perpaduan dari kedua nama karakter utama, yaitu Kuu dan Ket. Menggunakan font "Gogono Cocoa Mochi", font tersebut memiliki bentuk yang cartoonish. Kemudian penulis melakukan modifikasi dekorasi pada font tersebut, yaitu menambahkan garis-garis putus menyerupai jahitan, disini penulis ingin menggambarkan dua karakter utama yang di simbolisasikan jahitan dan dua warna yang berbeda. Penulis menambahkan efek drop shadow untuk memberikan dimensi pada judul.

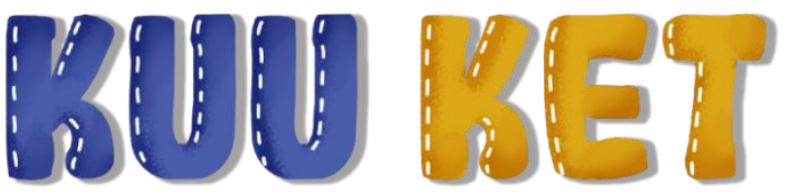

Gambar 1 Typeface Judul

Sumber: Dokumen Pribadi

\section{Kuu (Protagonis)}

Nama : Kuu

Horoscope : Cancer

Personality : Tenang, serius, protektif

Kuu adalah seekor anjing yang baik dan pendiam. Sebelum Kuu bertemu dengan sahabatnya, Ket. Kuu selalu sendirian, karena Kuu tidak mahir dalam mencari keasikan dengan sendirinya. Ketika Kuu bertemu dengan Ket, Kuu memiliki peran seperti seorang ibu kapada Ket.

Secara visual, Kuu memiliki bentuk dasar kotak. Bentuk dasar kotak untuk menggambarkan sifat Kuu yang serius. Kuu juga memiliki warna dasar biru, untuk menggambarkan sifat Kuu yang tenang.

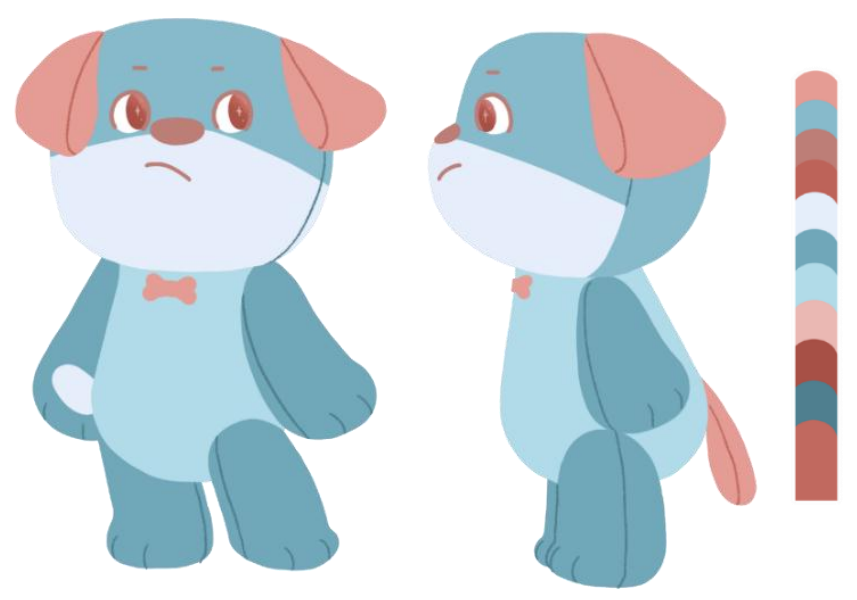

Gambar 2 Karakter Kuu

Sumber: Dokumen Pribadi 
Ket (Protagonis)

Nama : Ket

Horoscope : Aries

Personality : Ceria, energetic, ceroboh

Ket adalah anjing yang sangat aktif dan selalu semangat dalam menjalan aktivitas sehari-hari. Karena kesemangatannya, Ket selalu terjatuh atau terluka, berkat fisik Ket, yaitu bulu tubuhnya yang tebal, Ket terlindungi dari cedera yang serius. Sebelum Ket bertemu dengan sahabatnya, Kuu. Ket selalu sendirian dan cepat merasa bosan karena tidak ada teman yang bisa diajak untuk bermain bersama.

Secara visual, Ket memiliki bentuk dasar bulat. Bentuk dasar bulat untuk menggambar sifat Ket yang bersahabat. Ket juga memiliki warna dasar kuning, dengan tujuan menggambarkan sifat Ket yang ceria.
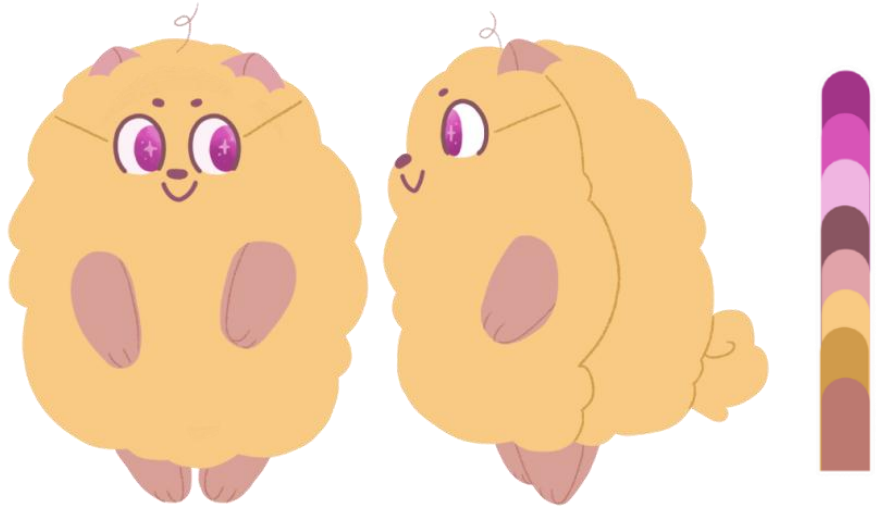

Gambar 3 Karakter Ket

Sumber: Dokumen Pribadi

\section{Buto (Antagonis)}

$\begin{array}{ll}\text { Nama } & \text { : Buto } \\ \text { Horoscope } & \text { : Capricorn } \\ \text { Personality } & \text { : Independen, pekerja keras }\end{array}$

Buto adalah pemilik Warung guguk nikmat. Warung guguk nikmat menyediakan masakan dengan daging anjing. Sebagai pemilik Warung guguk nikat, tentu Buto menjalankan perannya dengan serius. Buto menyiapkan segala jenis bahan masakan yang dibutuhkan dan juga memasaknya dan disajikan kepada konsumen.

Buto memiliki peran antagonis, yang dalam arti melawan karakter utama dalam animasi pendek ini. Melalui perspektif karakter utama, Buto adalah karakter jahat, karena Buto menangkap dan memproduksi karakter utama menjadi makanan yang siap disantap.

Karena peran Buto sebagai antagonis, Buto memiliki proposi tubuh yang mengitimidasi. Tubuhnya yang terlihat bongsor dan tanganya yang besar. Wajah Buto juga memiliki bentuk dasar segitiga, untuk menggambarkan perannya yang jahat. 


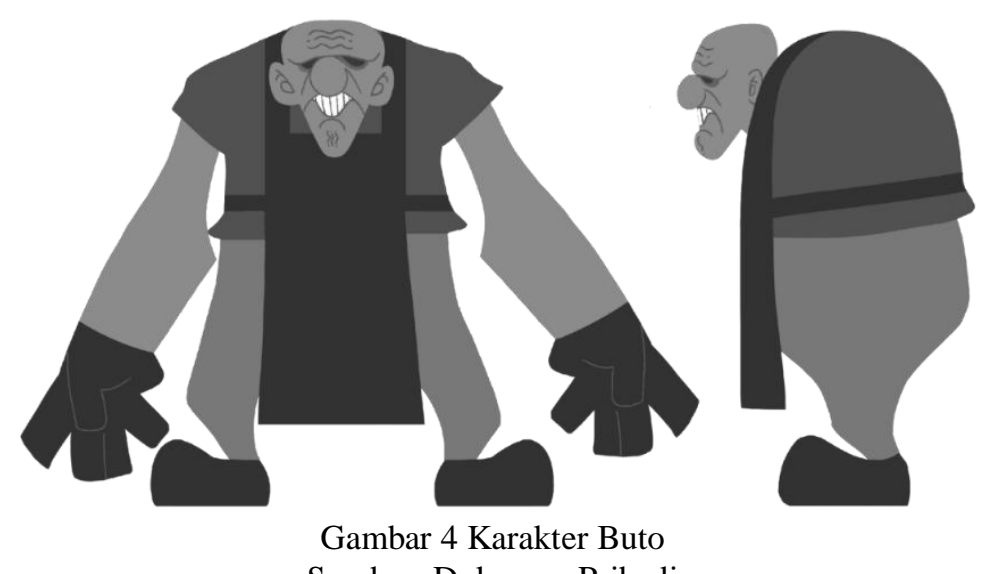

\section{Perancangan Environment}

Dunia visual environment dalam anaimasi pendek ini terbagi menajdi 2 , yaitu dunia dari perspektif karakter utama (dunia fantasi) dan dunia dari sudut pandang antagonis (dunia nyata). Dalam dunia fantasi, environment terbuat dari berbagai jenis permen-permen dan kudapan manisan lainnya, sedangkan dalam dunia nyata, berlokasi di "Warung Guguk Nikmat" milik sang antagonis.

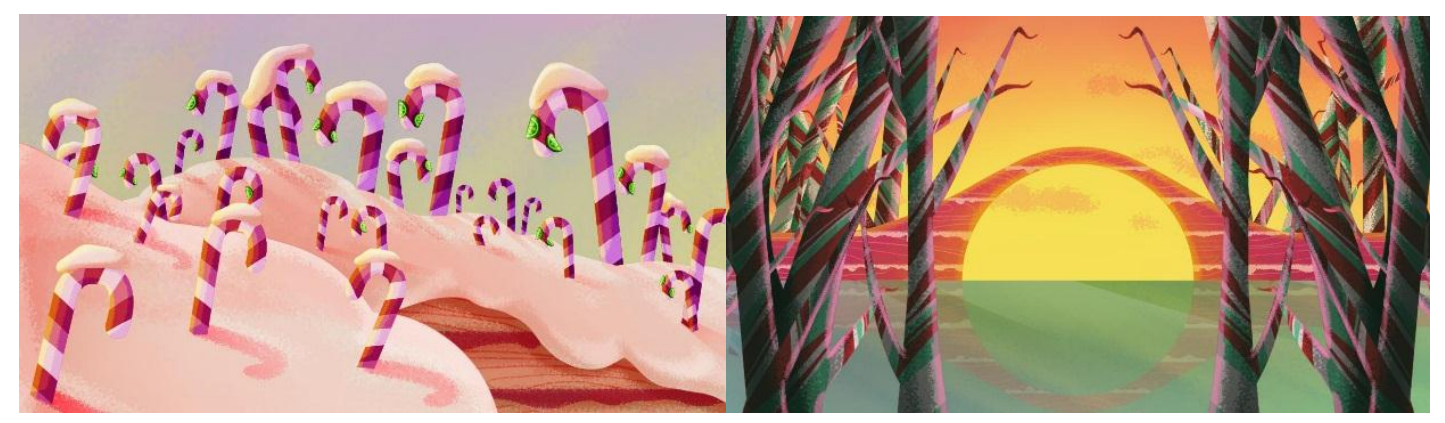

Gambar 5 Environment

Sumber: Dokumen Pribadi

\section{SIMPULAN}

Terinspirasi dari banyaknya kasus perdagangan dan konsumsi daging anjing di Indonesia, penulis ingin menyebarkan kejadian tersebut kepada masyarakat sekitar dengan format animasi pendek. Untuk melakukan perdagangan dan konsumsi daging anjing sendiri adalah suatu pelanggaran di Indonesia, sudah terdapat peraturan-peraturan yang menuliskan tentang perdagangan dan konsumsi daging anjing. Namun, masih banyak rakyat Indonesia yang masih menangkap anjing secara paksa dan memperdagangkan serta mengkonsumsi daging anjing secara illegal. Proses perdagangan daging anjing sendiri terjadi banyak kekejian di dalamnya, selain kekejian tersebut untuk mengkonsumsi daging anjing juga memiliki risiko buruk terhadap kesehatan konsumen. Mengonsumsi daging anjing dapat menyebabkan terinfeksi penyakit rabies dan zoonosis lainnya.

Penulis melakukan wawancara kepada ketua dari Animal Defenders Indonesia, Doni Herdaru Tona. Hasil dari wawancara tersebut penulis gunakan sebagai dasar pembuatan cerita animasi pendek. Penulis juga melakukan wawancara kepada Fierrany Halita, hasil wawancara tersebut akan digunakan sebagai basis pembuatan visual animasi pendek dan juga menarik perhatian target audisi. Untuk mendalami topik perdagangan daging anjing, penulis juga mencari data lainnya dari buku, jurnal, artikel, dan lainnya. Dari data didapatkan, penulis dapat merancang cerita dan desain visual untuk animasi pendek "Kuu Ket". 


\section{DAFTAR PUSTAKA}

Beetz, A., Moberg, K. U., Julius, H., \& Kotrschal, K. (2012). Psychosocial and psychophysiological effects of human-animal interactions: the possible role of oxytocin, 9 Juli. Diakses dari https://www.keulseweg.nl/media/onderzoek17.pdf

Coren, S. (1994). The intelligence of dogs. United States of America: Simon \& Schuster.Inc.

DMFI. (2018a). Pencuri bersenjata dan daging anjing yang terinfeksi rabies menyoroti bahaya perdagangan daging anjing dan kucing di Indonesia karena para pengkampanye khawatir akan risikonya terhadap para wisatawan. Diakses dari: https://www.dogmeatfreeindonesia.org/images/PDF/DMFIrabiesthreatpressrelease_Bah asaINDONESIA.pdf

DMFI. (2018b). Close down Indonesia's "extreme" live animal markets. Diakses dari https://www.dogmeatfreeindonesia.org/resources/extreme-markets

Hardoko, E. (2018). Dalam sehari, 1.200 anjing dikonsumsi di Kota Solo. Diakses dari: https://regional.kompas.com/read/2018/02/22/09123491/perjalanan-daging-anjing-dimedan-dari-pasar-hingga-piring-makan-1 ?page=all

IKAPI. (2018). Himpunan peraturan perundang-undangan KUHAP \& KUHP. Bandung: Fokusmedia.

Odendaal, J. S., \& Meintjes, R. A. (2003). Neurophysiological correlates of affiliative behaviour between humans and dogs. The Veterinary Journal, 165(3), 296-301.

PUSDATIN. (2016). Jangan ada lagi kematian akibat rabies. ISSN: 2442-7659.

Surat Edaran Ditjem Peternakan Dan Kesehatan Hewan (PKH) Kementan no.9874/SE/pk.420/F/09/2018

Undang-Undang No. 18 Tahun 2009 tentang Peternakan dan Kesehatan Hewan. Lembar Negara RI Tahun 2009, No. 84. Sekretariat Negara. Jakarta. Diakses dari: http://peraturan.go.id/uu/nomor-18-tahun-2009.html

Undang-Undang No. 42 Tahun 2014 tentang Perubahan atas Undang-Undang Nomor 18 Tahun 2009 Tentang Peternakan dan Kesehatan Hewan. Lembar Negara RI Tahun 2014, No 338. Sekretariat Negara. Jakarta. Diakses dari: http://peraturan.go.id/uu/nomor-41-tahun2014.html

Windratie. (2015). Kuliner daging anjing, cukuplah tercatat dalam sejarah. Diakses dari : https://www.cnnindonesia.com/gaya-hidup/20150424152302-262-49018/kulinerdaging-anjing-cukuplah-tercatat-dalam-sejarah 